\title{
TRADITIONAL MELODY VARIATIONS IN KARKSI PARISH (SOUTH-ESTONIA).
}

\section{Taive Särg}

Estonian regilaul (a special folk song), also runo song or Kalevala-song, has developed in deep connection with language. The prosodic qualities of the language should have left traces into old recitative melodies, which are the very

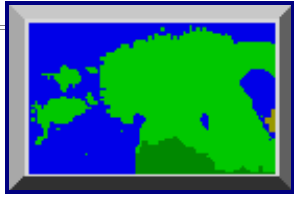
musical language of Estonia in its literal sense. The melody is of the descending contour like the Estonian speech intonation. (ex.*1) (ex.*2) The songs I have used in my present paper have been sung by the persons who had been born in Karksi parish, Southern Estonia, in the end of the previous century, and who had still experienced the unbroken tradition of runo song in their childhood. I have analysed 180 runo songs recorded in 1960-70s.

The melody of the runo song is repeated either by one or two verses, both consisting of 8 syllables. The melodies from Southern Estonia are especially variable. (ex.*3) Many of these changes are caused by the tradition, and we cannot determine the latitude of the singer without being familiar with the tradition.

Studying the variations of melodies, at first we have to answer the question, what these things are. Of the recent researchers, U. Kolk and I. Rüütel have tried to answer the question. The latter have said: "Variation is any deviation from the form of the song, its part or element, which has been chosen as a model for comparison"(Rüütel 1969, 95). In the same article she also says that the terminology of folk songs is internationally as vague as in our country.

So, when starting to study the melody variations, we have to choose the form of a song or its part for comparison as the first step. As the melody of the runo song (consisting of 8 syllable-notes), is repeated either by one or two verses, the basic form of the corresponding melody, which is the statistical mean of all variants used in this song, is taken as the model. (ex. *3) (Each independent recital or recording of a folklore item is considered a variant, a variant of a melody can be different for each verse.) (Rüütel 1969, 95).

Much more difficult is to determine, how marked - and which units of measurement should be used - should this deviation be, to be considered a variation. The problem is that the scale of sounds has not been firmly shaped and it can easily change in the course of the song. It is difficult to decide, for example, how many hertzes should a note (or several notes) alter in order to consider the line of melody different from the model, and thus - a variation. It is more reasonable to describe the marked changes in the basic contour of the line of the melody using melody steps, and leaving their variable absolute pitch undetermined.

I decided to divide the variations into two types according to their different nature. These types differ from each other not by the scope of the change, but by the nature and causes of the change.

1. Changes in the scale of sounds - changes the value of the steps - intonational changes.

2. Changes in the form of the melody - steps interchange positions - variations.

1. Changes in the scale of sounds may easily take place during the song, usually in the range of semitone, but sometimes even of the whole tone, which causes the change in intervals as well. Three singers under discussion use these changes. 
One of them, Kadri Kukk, is the least influenced by the more recent folk song, which is based on the diatonic scale of sounds. The changing scale of sounds, which K. Kukk consistently uses in her songs, is not a mistake or a shortcoming, but an original musical means of expression that gives her songs a special emotional charge. The fundamental tone changes only a little, and all other pitches are usually intoned higher at the beginning of the structural parts. The tension grows during the song, the pitches are lowered and the intervals reduced. If the neutral third is widened into the major third, it gives the songs an energetic and eager ring; if it is narrowed into the minor third, the songs sound sad, but if the minor third is reduced into the second, the songs gain a tragic ring. The minor third itself doesn't necessarily have to consist of a major and a minor second, as usual, but can be made up of two indefinite intervals. The position of the minor second in the third can also be changeable. In the songs of the quint range the tension is accumulated by fluctuation between pure quint and reduced quint. Such changes follow the subject of a song and render the emotions of the singer. The phenomenon can be more often found in long epic and lyrical songs. (ex. *4) The scale of sounds, which has not been clearly formed, refers to the closeness to speech, as the melody of speech is less regulated than that of a song.

The other, Ann Toompalu, in her turn, sings so much out of tune that no conclusions can be drawn about the line of melody on the grounds of her singing. But still, even her mistakes show some consistency now and then. The third singer, Anna Vari, uses in one song different basic tones, following the subject of a song. (ex. *5) Other singers use fixed scale, they have mastered the tradition of more recent folk song and their recital of runo song can possibly be influenced by this newer tradition. The recordings of changes in the scale or in intervals have been made in other regions of Estonia as well, so the phenomenon should not be untraditional, but rather a part of the one-voiced musical tradition, where fixed scale has not been developed as yet.

2. The melody variations, in their usual sense, represent the changes in the pitches outside the intonational fluctuation mentioned above. The notes are not characterized by their absolute pitch but by their order, beginning from the fundamental tone. This can better be described by steps, the mutual distance of which from each other is not firmly fixed, in such a way that they can be used for any scale. The alteration in the length of the line of melody by at least one metric unit and the increase in the number of notes because of the syllable division with different pitches can also be included in the melody variations.

The variations in melody, in this sense, are most often caused by linguistic reasons - the syllabic structure of a verse. The main changes take place in the case of 3-syllable words in a trochaic verse. The researchers have paid attention to these changes even earlier (H. Tampere 1937; I. Rüütel 1986, 244-253; U. Lippus 1977), but it is still not clear, in which case the occurrence of 3-syllable words causes a change in the line of melody and in which case it doesn't, and why. Some singers (Greete Jents, Ann Jõeste) use variations very rarely. We do not know whether it depends upon the habits of the singer, the local tradition, the type of melody or something else.

Trying to find some essential consistency, I set the problem as follows: if a 3-syllable word causes a change in melody, or the replacement of one turn of melody with another, then in which respect is the new turn of melody better and more congenial to the singer than the previous one had been? Which turns of melody are avoided and why?

I have classified the replaceable motifs according to their form and location in a verse. As a result of an analysis it was found that singers avoided quite consistently the situations, where the dropping interval of one pitch of a 2- or 3-syllable word would fall between the metrical feet. 
A 2-syllable word falls between the metrical feet in case the verse begins and ends with 3-syllable words (323 structure). The dropping second at this word will be replaced with a prime or an ascending second in case, when both the second and third metrical feet consist of the notes of one and the same pitch. (ex. *6B) Variations will not occur, if the melody is of different form. (ex. *7) So the variations of this type depend point-blank on the type of melody.

The variations in a 3-syllable word depend on whether it begins on ictus or nonictus, meaning that it depends on the quantity of the word. If a word begins on ictus, with a syllable of long main stress, the situations where the first drop in melody occurs only on the third syllable, (as the first and the second syllables are either of equal or rising pitch), can be avoided. (ex. *6A) If a 3-syllable word begins on nonictus - the syllable of short quantity - the drop in melody on the second syllable is avoided. (ex. *6C) Probably this is connected with the fact that the words of different quantity have different speech melodies, with which the recitative melody cannot get into conflict.

The singing of the 9-syllable verses or longer ones poses a different problem. If the verse includes at least two 3 -syllable (or $1+1+1,2+1,1+2$-syllable) words, it lengthens by one metric unit (ex. *8) The second syllable of a verse with 1233 structure has to be long to effect this change (ex. *9); if the second syllable is short, only a variation in rhythm takes place and two syllables fill the position of one. (ex. *10)

Sometimes melody variations occure at the beginning of the song and at beginnings of structural parts. (ex.*3) (ex.*5)

We can conclude that the changes are rather caused by the content of the song; the variations in the line of melody are caused by the language used, too, the syllabic structure of the verse, or rather, by its form. Of course we can say that the linguistic changes also serve the rendering of the meaning, as the language itself is a means of rendering cognitive meaning. The text and the melody of a song are still in a syncretic unity in this case. We also have to bear in mind that the recital of a song was often connected with an accompanying activity of some kind, which surely affected the performance.

The changes, which might have no importance in the diverse modern world, have their well-marked positions in a runo song. This is a song of the people, whose environment is clean of noise. For example, it happened once that during a recording K. Kukk interrupted the recital complaining that she 'cannot' continue. While relistening the tapes to follow the variations, I discovered that she had sung the melody of one three-syllable word out of tune by one step, and had got so confused that she had not been able to continue immediately.

If a song is recited without any variations, the cause may be that the contour of its melody has been shaped in the way that, when 3-syllable words are used in the verse, no 'prohibited' situations will arise. (ex.*11) The song tradition of the Karksi parish is very archaic and therefore we can hope that the regularities discovered in the materials could help us to notice other possible occurrencies of the kind in the whole culture of the runo song.

\section{References}

Rüütel, Ingrid 1969: Rahvalauluterminoloogia probleeme [Problems of the terminology of folk songs]. Keel ja Kirjandus. 1969:2.

Tampere, Herbert 1937: Eesti vana rahvalaulu rütmiprobleemist [About the problem of rhytm of Estonian old folk song]. Tartu. 
Rüütel, Ingrid 1986: O komponentakh muzykalnogo udarenia v runicheskoi pesne na materiale akusticheskikh issledovania vodskikh $\mathrm{i}$ estonskikh svadebnykhnapevov. [About components of the musical stress in runo song (on material of the acoustical investigations of Estonian and Votic wedding songs]: Muzyka v svadebnom obriade finno-ugrov $i$ sosednykh narodov. Tallinn, p. 244253.

Lippus, Urve 1977: O nekotorykh strukturnykh svoistvakh estonskikh runicheskikh napevov i o vozmozhnosti ispolzovania ikh pri sistematizaci napevov [About some structural features of Estonian runo tunes and about using them by systematizysing of melodies] : Problemy taksonomi runicheskikh melodi.Tallinn, p. 5-55. 